\title{
Motivasi Pilihan Karir bagi Remaja pada Masa Pandemi Covid-I9
}

\author{
Motivational Career Choices for Youth \\ during the Covid-19 Pandemic
}

\author{
Rina Juliyanti \\ Nur Azizah \\ IAIN Purwokerto, Cilacap, Jawa \\ Tengah, Indonesia \\ IAIN Purwokerto, Banyumas, jawa \\ Tengah, Indonesia \\ *email: rinajuliyanti23@gmail.com \\ nurazizah@iainpurwokerto.ac.id
}

\begin{abstract}
Abstrak
Bidang ekonomi, politik, sosial, budaya, hingga pendidikan kini mengalami perubahan karena pandemi Covid-19. Pandemi Covid-19 berdampak pada lulusan yang tinggal dirumah sehingga menyebabkan meluapnya angka pengangguran. Kebanyakan orang hanya menyorot pada sisi negatif pandemi, padahal kita juga berinovasi memanfaatkan peluang dari adanya pandemi Covid-19 untuk hal yang bermanfaat. Motivasi pemilihan karir bertujuan membantu siswa memilih karir melalui bimbingan karir. Bimbingan Karir dimaksudkan untuk membantu siswa agar kenal dan paham akan dirinya, mengenal dunia kerja, serta dapat merancang masa depan yang sesuai dengan bentuk kehidupan yang diharapkan, dapat bertanggungjawab atas keputusan yang diambil secara tepat, sehingga menciptakan pribadi yang bermakna. Dalam penelitian ini menerapkan program bimbingan karir pada delapan remaja lulusan SMA di desa Wlahar. Metode yangdigunakan yaitu dengan diadakan Workshop "Motivasi Pilihan Karir Bagi Remaja Pada Masa Pandemi Covid-19 Di Desa Wlahar" dengan teknik self managemen. Keberlanjutan kegiatan ini yaitu dengan mengadakan sesi konseling kelompok kepada para lulusan yang terkait dengan perencanaan karir. Hasilnya para remaja mau mencoba memulai karir dengan berwirausaha bisnis online.

Kata Kunci: Motivasi; Bimbingan Karir; Remaja; Pandemi Covid-19
\end{abstract}

\section{Kata Kunci:}

Motivasi

Bimbingan Karir

Remaja

Pandemi Covid-19

\section{Keywords:}

Motivation

Career Guidance

Youth

The Covid-19 pandemic

\section{Accepted}

Maret 2021

Published

April 2021

\begin{abstract}
The fields of economy, politics, social, culture, and education are now experiencing changes due to the Covid-19 pandemic. The Covid-19 pandemic has an impact on graduates who live at home, causing an increase in unemployment. Most people only focus on the negative side of the pandemic, even though we are also innovating to take advantage of the opportunities from the Covid-19 pandemic for useful things. Career selection motivation aims to help students choose careers through career guidance. Career Guidance is intended to help students know and understand themselves, get to know the world of work, and be able to design a future that is in accordance with the expected life form, can be responsible for decisions taken appropriately, thus creating a meaningful personality. In this study, applying a career guidance program to eight teenage high school graduates in Wlahar village. The method used was to hold a workshop on "Motivation for Career Choices for Youth During the Covid-19 Pandemic in Wlahar Village" with self-management techniques. The continuation of this activity is by holding group counseling sessions for graduates related to career planning. The result is that teenagers are willing to try to start a career by starting an online business entrepreneurship.
\end{abstract}

Keywords: motivation; Career Guidance; Youth; The Covid-19 pandemic

\footnotetext{
(C) 2021 The Authors. Published by Institute for Research and Community Services Universitas Muhammadiyah Palangkaraya. This is Open Access article under the CC-BY-SA License (http://creativecommons.org/licenses/by$\mathrm{sa} / 4.0 /)$.
}

\section{PENDAHULUAN}

Masa pandemi Covid-19 memberikan dampak bagi banyak pihak mulai dari bidang ekonomi, sosial, budaya, perusahaan maupun UMKM. Perusahaan besar ternama juga ikut merasakan, fakta lain juga tidak sedikit perusahaan memutuskan untuk memulangkan ataupun mem-PHK karyawannya. Hal ini menyebabkan angka pengangguran semakin meningkat dan peluang kerja semakin sedikit. Namun dalam masa seperti ini 
karyawan yang telah di PHK serta siswa yang baru diluluskan belum bisa memanfaatkan peluang kerja karena kini kian berkurang. Kondisi seperti ini mereka harus bisa membaca peluang yang ada untuk bisa mendapatkan penghasilan.

Bila kita terfokus pada dampak negatif pandemi saja maka akan tertinggal, namun ketika kita mampu melihat peluang yang ada maka banyak peluang baru yang bisa dikembangkan. Selama masa pandemi kita tetap harus memperhatikan protokol kesehatan seperti social and physical distancing, tetap dirumah saja melainkan ada kepentingan yang sangat penting. Kebutuhan sehari-hari tetap harus terpenuhi seperti kebutuhan primer makan, minum, kesehatan, pendidikan dan pakain. Orang yang mampu melihat peluang serta mampu melakkukan invosi baru dapat memanfaatkan kondisi seperti ini untuk memilih karir sesuai dengan kondisi saat ini yaitu bisnis online. Sebagai pemula hal ini pasti masih sulit maka dari itu perlu adanya motivasi sebagai dorongan untuk memulai usaha bisnis online.

Motivasi merupakan kekuatan dalam diri individu untuk melakukan tujuan tertentu atau dalam pengertian lain motivasi dapat diartikan sebagai suatu bentuk usaha yang tepat oleh individu untuk melakukan proses pencapaian tujuan yang dikehendaki sampai pada tujuan itu tercapai (Nurmastadiyah, 2009).

Motivasi dasarnya adalah mencoba mempengaruhi seseorang untuk dapat mewujudkan segala impiannya. Terdapat dorongan dari luar untuk bisa memaksimalkan apa yang menjadi tujuannya. Motivasi belajar dan pemilihan karir siswa dapat meningkat jika ada kejelasan pilihan karir yang dituju. Siswa giat belajar dan mau bekerja keras untuk mendapatkan penghargaan secara financial dan nonfinansial dalam wujud pengembangan bakat. Keberhasilan karir seorang siswa dapat dipengaruhi oleh seberapa besar kerja keras dalam mendapatkan tujuannya.
Karir disebut sebagai suatu keahlian profisional individu dalam suatu bidang dari kontribusi suatu organisasi dan menjadi pengalaman kerja (Nurmastadiyah, 2009). Karir sering dikaitkan dengan istilah job, employment, occupation, namun karir memiliki arti yang lebih luas. Geysbers menyatakan sebagaimana dikutip oleh Rahmi dalam Erni Nur Syamsiah, karir didefiniskan secara arti luas. Istilah karir tidak hanya menggambarkan pekerjaan namun mencakup seluruh askep kehidupan yang meliiputi peran hidup (life-role), lingkungan hidup (life-setting), dan peristiwa hidup (life-event) (Syamsiah, 20I2).

Karir dapat puladiartikan sebagai perjalanan atau pengalaman kerja seorang individu melalui rangkaian sikap sepanjang kehidupan kerjanya dan menjadi bentuk kesuksesan terhadap pilihan pekerjaannya dengan harapan memperoleh keuntungan finansial serta kebermaknaan hidup. Berdasarkan uraian-uraian yang telah dijelaskan menunjukkan bahwa karier memegang peran penting dalam kehidupan seseorang yang tidak hanya bertujuan muntuk mendaatkan keuntungan secara financial saja, namun sebagai wadah pengaktualisasi dan mengekspresikan diri dalam kehidupan sebagai kebermaknaan hidup. Motivasi untukberkarir merupakan dorongan untuk meningkatkantimbul kemampuan pribadi dalam mencari karir yang baik (Nurmastadiyah, 2009).

Perkembangan karier merupakan aspek dari perkembangan total individu yang menitikberatkan pada proses memberikan materi, melakukan persiapan dalam mempersiapkandunia kerja, serta kemajuan dalam bekerja (Gibson \& Mitchell, 20II). Apabila seseorang ingin mencapai karier secaraoptimal, maka harus mampu mengidentifikasi pilihan-pilihan karier, mampu mengeksplorasi informasi karier, serta mampu membuat sebuah keputusan karier. Dengan demikian, seseorang yang ingin mencapai karier secara optimal, maka harus mampu mengidentifikasi pilihan-pilihan karier, serta mampu menggali dan memahami informasi karier, agar mampu membuat keputusan karier. 
Efikasi diri dalam pengambilan keputusan karir memiliki kemampuan prediksi dari kesulitan pengambilan keputusan karir ketika mengontrol informasi latar belakang pengambilan keputusan karir pada individu (Chuang, Lee, \& Kwok, 2020). pengembangan karir dan identitas diri, terutama dalam kaitannya dengan pengembangan keterampilan dan struktur dapat membingkai identitas karier (Bimrose et al., 2019).

Havighurst membahas perkembangan karier sebagai proses seumur hidup yang terdiri atas enam tahapan yang dimulai sejak masa kanak-kanak hingga berusia senja (Gibson \& Mitchell, 20II). Tahap-tahap tersebut dijelaskan dalam tabel berikut ini.

Tabel I. Tahap Perkembangan Kerja dari Havighurst:

\begin{tabular}{|l|}
\hline Tahap - tahap perkembangan kerja \\
\hline I. Pengidentifikasian dengan seorang \\
pekerja Biasanya ayah, ibu, atau pribadi \\
signifikan lain. Konsep bekerja menjadi \\
bagian esensial pembentukan ego-ideal
\end{tabular}

2. Mencapai kebiasaan dasar bekerja keras dan gigih berjuang Belajar mengorganisasikan waktu dan energi untuk memastikan suatu pekerjaan selesai. Biasanya fokus pada tugas rumah, ujian, makalah, dIl. Belajar untuk mengedepankan pekerjaan daripada bermain, namun tetap bermain apabila pekerjaan sudah selesai.

\section{Mencapai identitas sebagai pekerja/profesi dalam struktur pekerjaan/profesi tertentu Memilih dan mempersiapkan diri untuk sebuah pekerjaan. Mendapatkan pengalaman bekerja merupakan basis bagi pilihan kerja selanjutnya dan memastikan kemandirian ekonomi di masa depan.}

4. Menjadi pribadi yang produktif Berusaha menguasai keterampilan disuatu pekerjaan. Berusaha menaiki tangga keahlian dan jabatan yang tersedia.

\section{Mempertahankan kedudukan} sebagai warga masyarakat yang produktif Menekankan pergeseran menuju masyarakat dan mulai mengurangi fokus kepada aspek-aspek individual sebagai pekerja. Individu tampak sebagai anggota masyarakat yang produktif serta memberi perhatian bagi tanggung jawab sipil yang
Usia

5-10

dilekatkan pada pekerjaan/kariernya. Individu berada dipuncak karier dan memiliki energi dan waktu untuk terlibat dalam aktivitas sosial yang lebih luas.

\section{Mengkontemplasikan hidup yang} produktif dan bertanggungjawab Individu sudah pensiun dari pekerjaannya atau menarik diri dari peran sebagai pekerja serta mulai merenungkan dan mengkaji semua pengalaman kerja dan pengalaman kariernya, melihat kontribusi sosial yang sudah dilakukan, dan sangat senang dengan hal ini. Meskipun mungkin tidak berhasil mencapai ambisinya, namun bisa menerima hidupnya dan yakin dirinya seorang individu yang produktif.

Menurut teori Perkembangan Kerja dari Havighurst pencapaian karir seseorang itu melalui serangkaian perekmbangan di mulai dari anak-anak hingga tidak memiliki jabatan lagi (Putra, 20I5). Pencapaian karir seseorang melalui berbagai pengalaman serta keberhasilan pencapaian hidup. Oleh karena itu pemilihan sebuah karir seseorang terbentuk melalui persiapan, perencanaan, pembelajaran, pengambilan keputusan, serta pengaktualisasian diri untuk mencapai kebermaknaan hidup (Putra, 20I5).

Pemilihan karir menurutForer dalam penelitiian Dewa Ketut Sukardi menyatakan bahwa pemilihan karier adalah suatu tindakan ekspresif yang memproyeksikan motivasi, pemahaman diri, informasi karier, dan kemampuan seseorang. Setiap pilihan karier menunjukkan sebuah pandangan hidup yang tidak hanya menetapkan fungsi-fungsi atau keterampilan kerja secara terpisah (Sukardi, 1993).

Pemilihan karir dipengaruhi beberapa faktor yang mempengaruhi yaitu, psikologis, sosiologis, ekonomis, kultural geografis, pendidikan serta kesempatan yang terbuka (Winkel \& Hastuti, 2006). Dari berbagai Faktor-faktor tersebut saling berhubungan satu sama lain sehingga membentuk sebuah jabatan bagi seseorang. Seorang individu memiliki sejumlah keyakinan, kebutuhan, kemampuan, keterampilan, pemahaman dan pengetahuan diri yang berkaitan dengan karier yang dipilihnya. Holland 
mengemukakan bahwa interaksi antara faktor hereditas mampu mempengaruhi dalam memilih pekerjaan atau memilih jabatan serta dapat juga dipengaruhi oleh orangtua, dan faktor lingkungan sosial yang berperan penting dalam pemilihan karier seseorang (Sukardi, 1993).

Teknik pemilihan karir pada masa pandemi Covid-19 dalam penelitian ini menggunakan teknik Self Management. Self managementupaya individu dalam melakukan aktivitas sebagai upaya untuk melakukan perencanaan dan melakukan evaluasi terhadap aktivitas yang dilakukan. Dalam teknik Self Managementada suatu ikatan psikologis yang mempengaruhi individu dalam mengambil keputusan untuk menentukan pilihan dengan strategi yang efektif.Selfmanagementdisebut juga sebagai upaya memperbaiki perilaku yang mengarakan perilaku individu dengan teknik terapeutik (Suwanto, 2016). Teknik self management disebut sebagai teknik untuk mempengaruhi seorang individu dalam mengambil keputusan bedasarkan rangsang dengan pendekatan cognitive behavior therapy. Pengambilan keputusan dimulai dari mengenal akan diri individu kemudian melakukan pemantauan secara mandiri dan berjanji atas keputusannya. Teknik ini merupakan ketrampilan individu untuk meningkatkan kematangan pilihan karir (Suwanto, 2016).

Kemampuan individu dalammenguasai tugastugas serta perubahan-perubahan dalam perkembangan karier serta kesiapan dalam pememilih karier yang tepat dilihat dariusia dan tingkat perkembangan merupakan kematangan karir. Dengan demikian, pemilihan karier merupakan keputusan yang didasari atas pengetahuan dan informasi yang dimiliki mengenai bidang studi atau pekerjaan tertentu, serta keberhasilan dalam menguasai tugas-tugas perkembangan.

\section{METODOLOGI}

Penelitian ini merupakan jenis penelitian kualitatif. Menurut Kirk dan Miller penelitian kualitatif merupakan penelitian yang dihasilkan berdasarkan pengamatan manusia dengan orang disekitarnya berasarkan ilmu sosial (Gumilang, 2016).

Subyek penelitian ini adalah delapan remaja lulusan SMA di desa Wlahar. Subjek penelitian masih memiliki banyak kegundahan ketika di tanya mengenai cita-cita, apalagi untuk karir belum ada pemilihan. Ditambah lagi pandemi Covid-19 ini mengurangi peluang kerja dan menurunnya minat melanjutkan kuliah. Oleh karena itu, peneliti memilih delapan remaja lulusan SMA ini sebagai subyek penelitian. Diharapkan workshop motivasi pemilihan karir ini mampu membantu remaja memilih karirnya. Bukan hanya dari skill, bakat dan minatnya saja melainkan kemampuan dalam melihat peluang yang ada dengan kemampuan memanfaatkan situasi dilingkungannya.

Penyajian dan pemaparan penelitian ini menggunakan penelitian kualitatif deskriptif dengan proses memperloeh data yang bersifat apa adanya. Data yang diperoleh nantinya berasal dari wawancara, observasi, dan dideskripsikan secara sistematis. Hasil penelitian yang diperoleh berupa kalimat tertulis maupun lisan serta informan (A'la, 2017). Peneliti menggali informasi melalui konseling kelompok ketika kegiatan workshop.

Peneliti menggunakan dokumentasi berupa data angket sebagai data awal. Sebelum mengikuti workshop motivasi pemilihan karir para remaja diharuskan untuk mengisi angket tersebut. Angket ini akan menginformasikan pilihan karir yang ada pada diri mereka hasil dari data angket itu akan di gunakan sebagai bahan diskusi pada konseling kelompok.

\section{HASIL DAN PEMBAHASAN}

Kegiatan workshop motivasi pemilihan karir bagi remaja pada masa pandemi covid-19 merupakan salah satu bentuk kontribusi untuk membantu remaja 
yang sudah lulus sekolah (alumni) agar mampu membaca peluang di masa pandemi. Kegiatan ini bertujuan untuk memotivasi para lulusan agar dapat meningkatkan rasa percaya diri untuk berwirausaha. Kondisi pandemi ini mengecilkan peluang mendapatkan pekerjaan, sehingga diharapkan mereka tergerak untuk membuka peluang pekerjaanuntuk diri mereka sendiri serta orang di sekitarnya. Terlebih lulusan ini adalah anak remaja yang sudah mengenal android jadi diharapkan mereka mampu memanfaatkan android sebagai toko online untuk memulai berwirausaha.

Workshop pemilihan karir diikuti oleh delapan peserta sekaligus menjadi subyek penelitian. Dalam kegiatan workshop para lulusan dikenalkan berwirausaha melalui bisnis online. Bisnis online dipilih sebagai wirausaha karena bisnis online bersifat fleksibel, kapan saja dan dimanapun kita berada bisnis online bisa dijalankan karena toko dalam genggaman. Bisnis online merupakan salah satu industri yang potensial. Dewasa ini bisnis online menjadi trend dikalangan masyarakat dunia termasuk Indonesia (Situmeang, 2018). Dalam menjalankan bisnis online para lulusan dapat memanfaatkan beberapa akun sosial media seperti whatsApp, instagram, facebook, web jualan dan lain-lain. Namun kita dapat memanfaatkan media sosial yang biasa digunakan oleh anak muda sekarang seperti whatsApp. WhatApp selain banyak digunakan oleh remaja juga banyak kalangan yang memanfaatkan sebagai komunikasi sehari-hari. Pada kesempatan workshop ini para lulusan dikenalkan wirausaha melalui bisnis online dengan memanfaatkan whataApp serta facebook, karena banyak orang yang memanfaatkan whatsApp sebagai komunikasi seharihari dan memanfaatkan facebook sebagai toko online. Para remaja lulusan membuat akun facebook dengan profil bio yang menarik. Dalam workshop para remaja juga dikenalkan cara membuat iklan yang menarik dengan menafaatkan aplikasi storyart. Para remaja ini sangat antusias dalam mengikuti pembelajaran, mereka langsung dapat mengikuti praktik membuat iklan menarik kemudian diuplikasikan di whatsApp.

Pengenalan bisnis online, membuat bio yang informative pada akun facebook serta praktik membuat iklan menarik selesai dilanjutkan dengan konseling kelompok. Menurut Harrison dalam penelitian Kurnanto, konseling kelompok merupakan layanan yang membantu peserta didik mengentaskan masalah anggota kelompok melalui dinamika kelompok (Indriasari, 2016). Dalam konseling kelompok remaja akan diajak untuk mendiskusikan kematanga pilihan karir yang mereka minati serta memilih mana yang bisa diterapkan ditengah pandemi.

Sebelum konseling kelompok dimulai pemimpin mengenalkan diri sebagai pemimpin serta mempersilahkan anggota yang lain untuk memperkenalkan diri. Anggota konseling kelompok terdiri dari delapan remaja.Teknik pemilihan karir yang diterapkan dalam konseling kelompokmenggunakan teknik selft management. Sesuai tujuan dari self managementyaitu mengembangan perilaku yang lebih adaptif dari konseli yang mana melihat konsep dasar dari self managementadalah proses pengubahan tingkah laku dengan satu atau lebih melalui strategi pengelolaan tingkah laku internal dan eksternal individu (Suwanto, 2016). Oleh karena hal ini pemimpin kelompok mengarahkan para anggota kelompok untuk memilih karir yang dapat di kembangkan pada masa pandemi seperti ini yaitu dengan berwirausha bisnis online. Hal ini dapat diikuti oleh anggota kelompok, kemudian mereka memilih bidang wirausaha yang mereka minati sesuai dengan hobinya. Ada yang memilih usaha makanan, reseller baju dII.

Syamsu Yusuf dalam penelitian Feida Noorlaila Istiadah dkk menyebutkan perkembangan berpikir pada remaja diantaranya yaitu "Dapat memikirkan masa depan dimulai dari menyusun perencanaan untuk pencapaian”. Berdasarkan pendapat ini, seharusnya remaja mammpu menyadari bahwa dia harus memilih dan segera mempersiapkan karir yang tepat dengan 
potensi serta kondisi diri sekitarnya (Istia'dah et al., 2018).

Layanan bimbingan karir di Indonesia seharusnya memahami dan memenuhi kebutuhankebutuhan siswa dalam pemilihan karir, sehingga siswa yang lulus nanti sudah memiliki ketrampilan dalam menentukan pemilihan karir ketika meninggalkan bangku sekolah (Istia'dah et al., 2018). Hoyt mengemukakan macam-macam kebutuhan :a. Merencanakan persiapan pendidikan karir. b. mempersiapkan kecakapan dalam dunia kerja. c. memahami nilai-nilai daalam dunia kerja. d. Merancang persiapan pemilihan karir (Juwitaningrum, 2013).

Karir yang akan dipilih oleh lulusan ini harus dengan pertimbangan matang. Individu dikatakan telah siap atau telah matang dalam pemilihan karir jika pengetahuan kematangan pemilihan karirnya didukung informasi aktual mengenai pekerjaan berdasarkan pencarian yang telah dilakukan (Suwanto, 2016).

Kematangan karir remaja dapat dilihat dari empat aspek, diantaranya: diawali dari perencanaan yang meliputi kesadaran individu untuk memantapkan pilihan karir dan melakukan persiapan, individu menggali berbagai informasi tentang dunia kerja untuk memantapkan bidang pekerjaan yang dminati, memanfaatkan infromasi pemilihan karir untuk diterapkan oleh diri individu, mampu mempertimbangakan pemilihan karir dan sesuai dengan pekerjaannya (Suwanto, 20I6).

Kematangan karir melalui bimbingan kelompok dilakukan untuk memaksimalkan proses dalam pengembangan karir yang dilakukan melalui interaksi dalam kelompok, dengan saling bertukar informasi, memberikan saran serta masukan tentang cara-cara mempersiapkan diri untuk menentukan karir di depan (Rahmawati, Yusmansyah, \& Mayasari, 2020).

Penggunaan teknik Self Management sebagai penerapan pemilihan karir karena dianggap mampu dan sesuai dengan situasi sekarang. Self management bertujuan mengembangan perilaku yang lebih adaptif dari konseli. Self management memiliki konsep dasar diantaranya ada: (I) Proses mengubahan tingkah laku menggunakan satu atau lebih strategi melalui pengelolaan tingkah laku secara internal dan eksternal individu. (2) Penerimaan individu dalam program perubahan perilaku menjadi syarat dasar untuk menumbuhkan motivasi individu. (3) Partisipasi individu sebagai agen perubahan menjadi sangat penting. (4) Generalisasi dan tetap mempertahankan hasil akhir dengan langkah mendorong individu untuk menerima tanggung jawab dalam menjalankan strategi pada kehidupan sehari-hari. (5) Perubahan bisa dihadirkan dengan mengarahkan individu menggunakan ketrampilannya dalam menangani masalah. (6) Agar individu lebih mantap dalam menempatkan diri dalam berbagai situasi yang dapat menghambat tingkah laku yangmemungkinkan mereka hendak hilangkan dan belajar untuk mencegah timbulnya perilaku atau masalah yang tidak dikehendaki. (7) Individu mampumengelola pikiran, perasaan serta perbuatan sehingga mendorong pengindraan untuk meninggalkan hal yang kurang baik dan meningkatkan hal yang baik benar (Suwanto, 2016).

Setiap individu dihadapkan pada persiapan, pilihan dan pengembangan karir yang serba komprehensif dikaitkan pada kebutuhan kehidupan yang semakin kompleks ('Widyatmoko, Ayriza, \& Purwandika, 2019). Memahami potensi penting untuk melihat korelasi psikologis dari ketidaksesuaian aspirasi atau harapan karier untuk mengembangkan intervensi, program, kebijakan yang dapat mengurangi efek negatif tersebut bagi remaja. Secara umum, bisa dengan mengkonseptualisasikan dan merencanakan masa depan terkait dengan pola ketidaksesuaian aspirasi atau harapan karir remaja (Napolitano, Hoff, Ming, Tu, \& Rounds, 2020).

Keefektifan intervensi berbasis konstruksi karir yang dirancang bisa digunakan untuk mendorong aspek-aspek kunci dari pengembangan karir, bertujuan untuk menentukan peningkatan dalam adaptasi karir, 
harapan untuk masa depan yang dapat diperkirakan, optimisme, orientasi masa depan, dan ketahanan pada Remaja (Santilli, Nota, \& Hartung, 2019).

Pemilihan karir melalui teknik Self Management memanfaatkan wirausaha sebagai aplikator pemilihan karir di tengah pandemi. Perilaku manusia merupakan hasil darimerespons berbagai stimulus dari lingkungannya. Para lulusan diajarkan langsung membuat iklan yang menarik sebagai bekal. Tahapan dalam self management sebagai ini adalag sebagai berikut: (I) Peneliti mengidentifikasi subyek dari data form karir yang telah diisi oleh para lulusan sebelum mengikuti workshop. (2) Peneliti mengidentifikasi subyek secara langsung melalui konseling kelompok. (3) Peneliti menjelaskan kemungkinan strategi pengelolaan diri (self management) dengan memaparkan wirausaha bisnis online sebagai salah satu pilihan karir. (4) Subyek memilih beberapa strategi self management dari catatan mereka mengenai beberapa pilihan karir yang mereka minati. (5) Konselor memberi arahan dan strategi yang dapat di dipilih sesuai dengan kemampuan subyek. (7) Peneliti mereview pemahaman yang didapatkan subyek.

\section{KESIMPULAN}

Program layanan Bimbingan Karir sangat diperlukan khususnya untuk meningkatkan kematangan karir bagisiswa.Workshop motivasi pemilihan karir bagi remaja di tengah pandemi Covid-19 di Desa Wlahar menggunakan teknik selft management menunjukan respon yang baik, hal ini dapat dilihat dari keantusian para lulusan ketika mengikuti workshop. Dari program konseling kelompok para lulusan mendapatkan strategi pemilihan karir sampai pada mereka mampu memilih karir yang tepat mereka kembangkan di tengah pandemi.

Teknik konseling self management merupakan bantuan professional dengan seperangkat aturan sebagai upaya praktik bantuan profesional terhadap individu. Hal ini diharapkan agar individu mampu mengembangkan potensinya serta dapat memecahkan masalahnya dengan menerapkan prinsip dan prosedur terkait diri, dalam teknik self management memandang subyek adalah individu yang mampu belajar serta mengarahkan kelebihan diri. Seperti tujuan dari teknik Self management yaitu membantu subyek agar mengurangi perilaku negatif kemudian mengembangkan perilaku positif dengan cara mengamati diri sendiri, mencatat segala sesuatu terkait perilaku yang meliputi pikiran, perasaan, tindakan, interaksinya berdasarkan peristiwa lingkungan.

\section{SARAN}

Berdasarkan penelitian di atas, terdapat beberapa saran yang dapat digunakan sebagai bahan pertimbangan yaitu: (I) Guru BK sekolah diharapkan membekali siswa dalam pemilihan karir melalui tahap layanan bimbingan konseling dan meningkatkan layanan konseling individual sesuai dengan kebutuhan siswa seperti pilihan dan latihan keterampilan khusus, pemberian informasi seputar dunia kerja. (2) Untuk peneliti lebih selanjut, diharapkan dapat melakukan penelitian dengan memaksimalkan instrumeninstrumen seperti: permasalahan karier, minat karier, dan potensi yang dimiliki siswa, sehingga mempermudah dalam melakukan analisis, sintesis, diagnosis, prognosis, konseling, serta tindak lanjut.

\section{REFERENSI}

'Widyatmoko, W., Ayriza, Y., \& Purwandika, R. (2019). Analisis Faktor Konfirmatori sebagai Prosedur Evaluasi Konstruk Skala Kematangan Karir. Counsellia: Jurnal Bimbingan Dan Konseling, 9(I). https://doi.org/http://doi.org// 0.25273/counsellia. v9il.3689

A'la, M. A. Z. N. (2017). Penerapan Sholat Tahajud terhadap Penderita Stroke diKlinik Rumah Sehat Avicenna, Desa Tempurejo Kecamatan Pesantren Kota Kediri. Spiritualita: Journal of Ethics and Spirituality, I(I), 55-68. https://doi.org/https://doi.org//0.30762/spr.vlil.6 41

Bimrose, J., Brown, A., Mulvey, R., Kieslinger, B., Fabian, C. M., Schäfer, T., ... Dewanti, R. T. 
(2019). Transforming Identities and Coconstructing Careers of Career Counselors. Journal of Vocational Behavior, III, 7-23. https://doi.org/https://doi.org/10.1016/j.jvb.2018. 07.008

Chuang, N.-K., Lee, P. C., \& Kwok, L. (2020). Assisting Students with Career Decision-making Difficulties: Can Career Decision-making SelfEfficacy and Career Decision-making Profile Help? Journal of Hospitality, Leisure, Sport \& Tourism Education, 26. https://doi.org/https://doi.org//0.1016/j.jhlste.201 9.100235

Gibson, R. L., \& Mitchell, M. H. (20II). Bimbingan dan Konseling. Yogyakarta: Pustaka Pelajar.

Gumilang, G. S. (20|6). Metode Penelitian Kualitatif dalam Bidang Bimbingan danKonseling. Jurnal Fokus Konseling, 2(2). Retrieved from http://garuda.ristekbrin.go.id/documents/detail/5 11029

Indriasari, E. (20/6). Meningkatkan Rasa Empati Siswa melalui Layanan Konseling Kelompok dengan Teknik Sosiodrama pada Siswa Kelas XI IPS 3 SMA 2 Kudus Tahun Ajaran 2014/20I5. Jurnal Konseling Gusjigang, 2(2). https://doi.org/https://doi.org//0.24 I76/jkg.v2i2.7 18

Istia'dah, F. N. L., Imaddudin, A., Arumsari, C., Nugraha, A., Sulistiana, D., \& Sugiana, G. (20I8). Program Bimbingan Karir pada Siswa Kelas XII SMK Assaabiq Singaparna. ABDIMAS UMTAS: Jurnal Pengabdian Kepada Masyarakat, I(I), 3I40. Retrieved from https://journal.umtas.ac.id/index.php/ABDIMAS/a rticle/view/237

Juwitaningrum, I. (2013). Program Bimbingan Karir untuk Meningkatkan Kematangan Karir Siswa SMK. PSIKOPEDAGOGIA: Jurnal Bimbingan Dan Konseling, 2(2), |32-147. https://doi.org/http://dx.doi.org// 0.12928/psikop edagogia.v2i2.2580

Napolitano, C. M., Hoff, K. A., Ming, C. W. J., Tu, N., \& Rounds, J. (2020). Great Expectations: Adolescents' Intentional Self-Regulation Predicts Career Aspiration and Expectation Consistency. Journal of Vocational Behavior, 20. https://doi.org/https://doi.org//0.1016/j.jvb.2020. 103423

Nurmastadiyah, R. (2009). Pengaruh Motivasi terhadap Minat Mahasiswa Akuntansi Untuk Mengikuti Pendidikan Profesi Akuntansi (PPAk) (UIN suska Riau). Retrieved from http://repository.uinsuska.ac.id/I 1006/I/2010_2010302AKN.pdf

Putra, R. T. (20I5). Upaya Meningkatkan Kemampuan Pemilihan Karier Siswa melalui Konseling Kelompok dengan Pendekatan Trait-Factor pada Siswa Kelas $X$ Mia 2 Madrasah Alliyah Negeri (Man) I Yogyakarta Tahun Ajaran 20/4/20I5 (Universitas Negeri Yogyakarta). Retrieved from http://journal.student.uny.ac.id/ojs/index.php/fipb
k/article/viewFile/299/273

Rahmawati, A. R., Yusmansyah, Y., \& Mayasari, S. (2020). Pengaruh Layanan Bimbingan Kelompok Terhadap Kematangan Pilihan Karir. ALIBKIN (Jurnal Bimbingan Konseling), 8(2). Retrieved from http://jurnal.fkip.unila.ac.id/index.php/ALIB/article /view/204I7

Santilli, S., Nota, L., \& Hartung, P. J. (2019). Efficacy of a Group Career Construction Intervention with Early Adolescent Youth. Journal of Vocational Behavior, III, 49-58. https://doi.org/https://doi.org/10.1016/j.jvb.2018. 06.007

Situmeang, R. R. (20/8). Dampak Bisnis Online dan Lapangan Pekerjaan terhadap Peningkatan Pendapatan Masyarakat (Studi Kasus Jasa Bisnis Online Transportasi Grab Di Kota Medan). Asian Journal of Innovation and Entrepreneurship (AJIE), 4(3). Retrieved from https://journal.uii.ac.id/ajie/article/view/I I620

Sukardi, D. K. (1993). Analisis Inventori Minat dan Kepribadian. Jakarta: PT Rineka Cipta.

Suwanto, I. (20I6). Konseling Behavioral dengan Teknik Self Management untuk Membantu Kematangan Karir Siswa SMK. JBKI: Jurnal Bimbingan Konseling Indonesia, I(I). https://doi.org/http://dx.doi.org//0.26737/jbki.vli 1.96

Syamsiah, E. N. (2012). Profil Kematangan Karir Siswa Sekolah Menengah Atas Serta Implikasinya bagi Bimbingan Karir: Studi Deskriptif terhadap Siswa Kelas X SMA PGRI I Bandung Tahun Ajaran 20 I I2012 (Skripsi UPI Bandung). Retrieved from http://repository.upi.edu/10878/

Winkel, W. S., \& Hastuti, M. M. S. (2006). Bimbingan dan Konseling di Institusi Pendidikan. Yogyakarta: Media Abadi. 